\title{
Impact of Hymenoptera on Abelmoschus Esculentus (L.) Moench, 1794 (Malvaceae) Seed Yields at Bilone (Obala, Cameroon)
}

\author{
Pharaon Mbianda Auguste ${ }^{1 *}$, Douka Chantale ${ }^{2}$, Dounia ${ }^{2}$, Fernand - Nestor Tchuenguem \\ Fohouo $^{3}$ \\ ${ }^{1}$ Laboratory of Biological and Physiological Sciences, University of Douala, Faculty of Science, Douala, \\ Cameroon \\ ${ }^{2}$ Laboratory of Zoology, University of Yaoundé I, Higher Teachers' Training College, Yaoundé, Cameroon \\ ${ }^{3}$ Laboratory of Applied Zoology, University of Ngaoundéré, Faculty of Science, Ngaoundéré, Cameroon \\ *Corresponding Authors: Pharaon Mbianda Auguste, Laboratory of Biological and Physiological \\ Sciences, University of Douala, Faculty of Science, Douala, Cameroon
}

\begin{abstract}
In Bilone (Obala, Cameroon), during the mild raining season (March-June) in 2019 and 2020, the flowers of Abelmoschus esculentus (Malvaceae) were observed for the study of the activities of Hymenoptera and the determination of the impact of these insects on the yields seedlings of this Malvaceae. Treatments included unlimited floral access by all visitors and bagged flowers to avoid all insect pollinators. The results show that on flowers of A. esculentus, 9 species of insects were recorded. The Hymenoptera occupied the first rank with $84.76 \%$ of the visits. These bees prey on the flowers in the morning and evening, with a peak between 09 - 10 am. His visits correspond to a very good harvest of the nectar and a weak harvest of the pollen. Comparing the yields of free flowers to those of isolated insects, there is an increase in the number of seeds per pod of $20.59 \%$ in 2019 and 20.87 in 2020 and the percentage of normal seeds of $02.38 \%$ in 2019 and $5.28 \%$ in 2020 due to Hymenoptera. This improvement in yields is justified by the positive action of these arthropods on the pollination of the flowers they visit. Therefore, conservation of nests and colonies of Hymenoptera close to A. esculentus crop fields should be recommended to improve pod and seed production in the locality.
\end{abstract}

Keywords: Hymenoptera, Abelmoschus esculentus, flower, pollen, pollination, yield.

\section{INTRODUCTION}

Many plants depend on pollination for their production [1]. This pollination is motsly carried out by insects [2]. Effective pollination is followed by good fruiting or high seed production [3]. It produces many seeds, a suitable shape and size of fruit [4]. Insects and flowers perform mutual services, the main beneficiary of which is man. Such results are beneficial for agricultural development. In developing countries, more particularly Cameroon, whose economy is essentially based on agriculture [5], the role of pollinating insects in increasing agricultural yields is little known [6]. However, the absence of pollinating insects at the time of flowering can lead to insufficient fruit and / or seed yields in some crops [7]. In the natural environment as in agro-ecosystems, flower insects have great ecological and economic importance because they positively influence agro-food production $[8,9$, 10]. Most farmers in developing countries believe that the high yields are due exclusively to various cultivation techniques, nutrients and infestation control [11]. They ignore that in the presence of an insufficient number of them during the flowering of several plants, the yields can be greatly reduced or nil $[12,13,14]$.

Abelmoschus esculentus (L.) Moench (1794) is a Malvaceae from the tropics and subtropics widely cultivated in Africa [15]. Commonly called okra, lady's finger or gumbo is an important vegetable in the tropics and sub-tropics [16]. This crop plant probably originated in the Ethiopian region of Africa but is now widely grown throughout Africa; especially in Sudan, Egypt and Nigeria [16]. Up to $4 \mathrm{~m}$ tall, erect, more or less strongly branched; cylindrical stem, with stiff hairs disseminated, glabrescent, 
often spotted with red; branches set to curved downwards [16]. The leaves are arranged spirally, their color vary from clear to purplish red. Flowers are solitary, axillary and cream-colored, yellow or golden yellow with a dark red zone at the base of the petals [16]. Okra is self-compatible, and selfpollination can take place in its hermaphrodite flowers [17]. The flowers open in the early hours of dawn. Anthers are dehiscent at anthesis [16] and produces nectar and pollen which attract insects [13, 15, 17]. Previous results of Azo'o [18, 19] indicate that the flower of Okra is very deep; this makes it difficult for foragers to reach nectaries, which lie in its bottom. Its ephemeral, hermaphrodite, axillary and solitary flowers [20] attract insects [17, 21, 22]. Around the world, data concerning the relationship between A. esculentus and flower insects are exist but are insufficient. Crane [23] and Free [24] have shown that the bee Apis cerena and bees of the genus Halictus are the predominant pollinators of A. esculentus in India. In Burkina Fasso, Angbanyéré \& Matthew [25] reported that Apis mellifera is the major pollinator of this plant. In Cameroon, with the exception of the work carried out in Yaoundé by Njoya [21] and Amada [26], Maroua Azo'o [17, 18] and Pando [27] respectively, no other scientific production in this direction is available to our knowledge. These authors found that Apis mellifera, Megachile spp., Halictus spp. and Xylocopa spp. [21], Tetralonia fraterna and Eucara macrognata [18, 19], Lipotriches collaris [27], then Xylocopa olivacea, Synagris cornuta [26] are constant pollinators of A. esculentus and significantly increase the yields of this plant. Globally, the areas devoted to the cultivation of okra are estimated at 7 million hectares. In 1969, revenues generated by the export of okra by developing countries were estimated at more than $\$ 1.1$ billion [28]. In Cameroon, okra production which is estimated at 54,776.5 tonnes / year [28] is insufficient to meet demand estimated at 7,011,392 tonnes / year [5]. Previous work done on the pollination of flower-growing insects of A. esculentus carried out in Yaoundé by Njoya [21], Amada [26] and Maroua by Azo'o [18, 19], Pando [27], are urbanized areas. Knowing that the pollinating insects of a plant species can vary from one region to another, according that the diversity and abundance of the pollinating entomofauna of a plant can vary in time and space [29] and considering the need to increase okra yields in Cameroon, it is necessary to conduct research in an agricultural environment to supplement existing data. Thus, knowledge of the diversity of okra pollinating insects should allow the breeding of potential effective pollinating insects of this Malvaceae. More, no previous research has been reported on the relationships between A. esculentus and its anthophilous insects in Bilone. The main objective of this research was to gather more data on the relationships between $A$. esculentus and flower visiting insects for its optimal management in Cameroon. Specific objectives were: (a) to determine the place of insects in the floral entomofauna of this plant; (b) to study the activity of Hymenoptera on Abelmoschus esculentus flowers; (c) to assess the impact of flower-growing insects on the pollination of this Malvaceae; (d) to assess the impact of Hymenoptera on production of seeds yields of Abelmoschus esculentus in this locality.

\section{MATERIALS AND METHODS}

\subsection{Study Site, Experimental Plot and Biological Material}

The studies were conducted twice, April to July respectively in 2019 and 2020 in a field located at the campus of the Institute of Agronomy in Bilone (Obala) (Latitude: N 04.20514 ${ }^{\circ}$, Longitude: E 011.51694 ${ }^{\circ}$, Altitude: $525 \mathrm{~m}$ ) in the Center Region of Cameroon. This Region belongs to the tropical rain forest agro-ecological zone [30]. The climate is equatorial guinean-type with four seasons: the peak rainy season (August to November), the peak dry season (November-March), the mild rainy season (March-July) and the mild dry season (July-August), the mean annual temperature is $25^{\circ} \mathrm{C}$, while the mean annual relative humidity is $79 \%$ [31]. The experimental plot was an area of $544 \mathrm{~m}^{2}$. The animal material was represented by insects naturally present in the environment and four colonies of A. mellifera (Hymenoptera: Apidae) inhabiting six of the six beehives located at 22 meters from the experimental field (Fig. 1). Vegetation was represented by wild species and cultivated plants. The plant material was represented by the seeds of A. esculentus bought at the Mfoundi market in Yaoundé (Cameroon) (Fig. 2). 


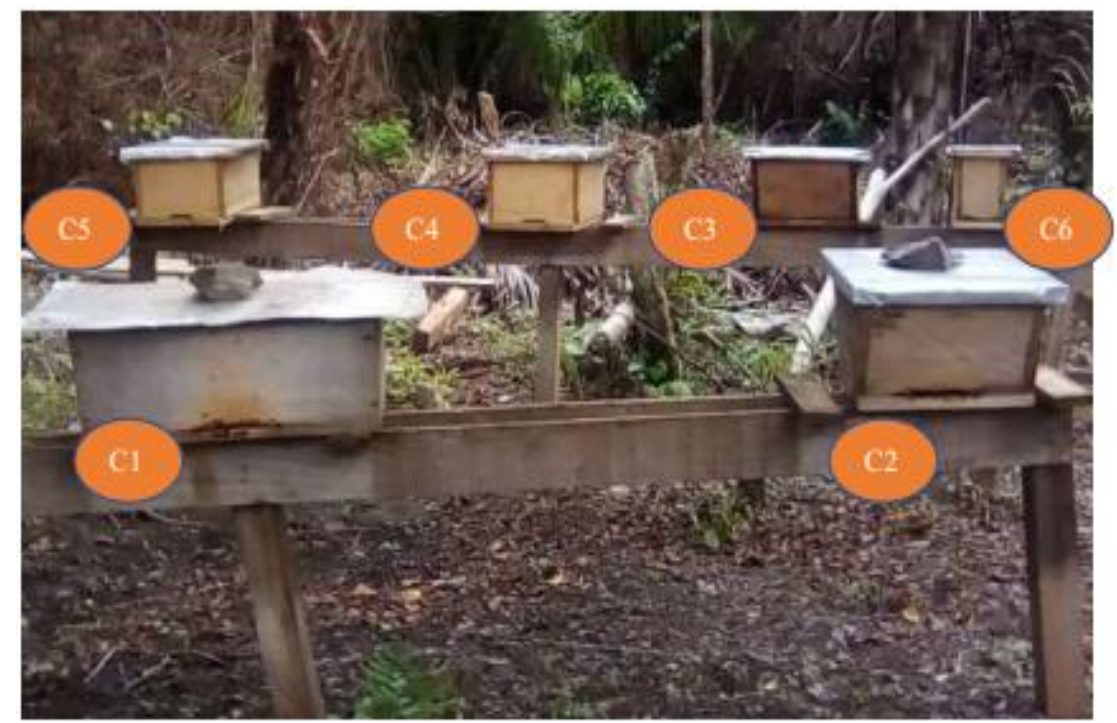

Figure1. Six upper striped hives each housing a colony of Apis mellifera in Bilone in 2019.
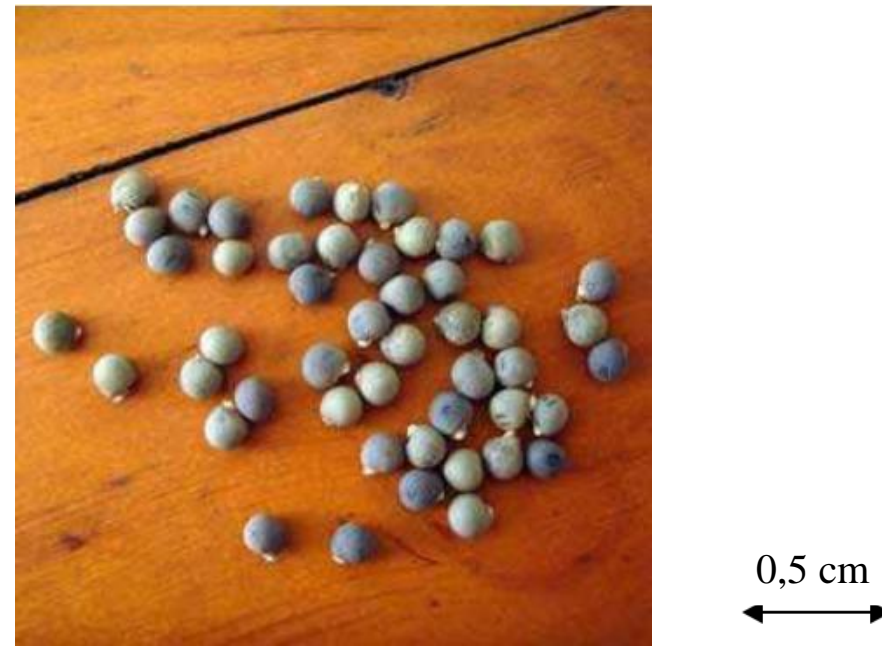

Figure2. Seeds of Abelmoschus esculentus

\subsection{Sowing and Weeding}

On March 26, 2019 and March 17, 2020, the experimental plot was divided into fifteen ridges of 8 meters. Seeds were sown on one line per ridges; each line had fourteen holes and each hole received four seeds. The spacing was $50 \mathrm{~cm}$ between rows and $2 \mathrm{~m}$ between ridges. Each hole was $4 \mathrm{~cm}$ depth. Two weeks after germination, the plants were thinned and only two were left per hole. Weeding was performed manually as necessary to maintain subplots weeds-free.

\subsection{Determination of the Reproduction System of Abelmoschus Esculentus}

In May 08 and 22 respectively in 2019 and 2020, 70 flowers of A. esculentus at the bud stage were labeled. 35 of the total number flowers were allowed for treatment 1 (open pollination) (Fig. 3) and 35 others flowers belong to treatment 2 (bagged with gauze bags to prevent visitors or external pollinating agents) (Fig. 4) [32]. For each year, ten days after the wilting of the last flower, the number of pods formed in each treatment was counted. For each treatment, the fruiting index (Ifr) was then calculated using the following formula: $I f r=(\mathrm{F} 1 / \mathrm{F} 2)$, where $F 1$ is the number of pod formed and $F 2$ the number of viable flowers initially labeled (Tchuenguem, 2005). The out crossing rate (TC) was calculated using the formula: TC $=\{[(I f r I-I f r 2 / I f r l] * 100\}$, where Ifrl and Ifr2 are mean fruiting indexes in treatments 1 and 2 respectively (Tchuenguem, 2005). The rate of self-pollination in the broad sense $(T A)$ was calculated using the formula: $T A=(100-T C)$. 


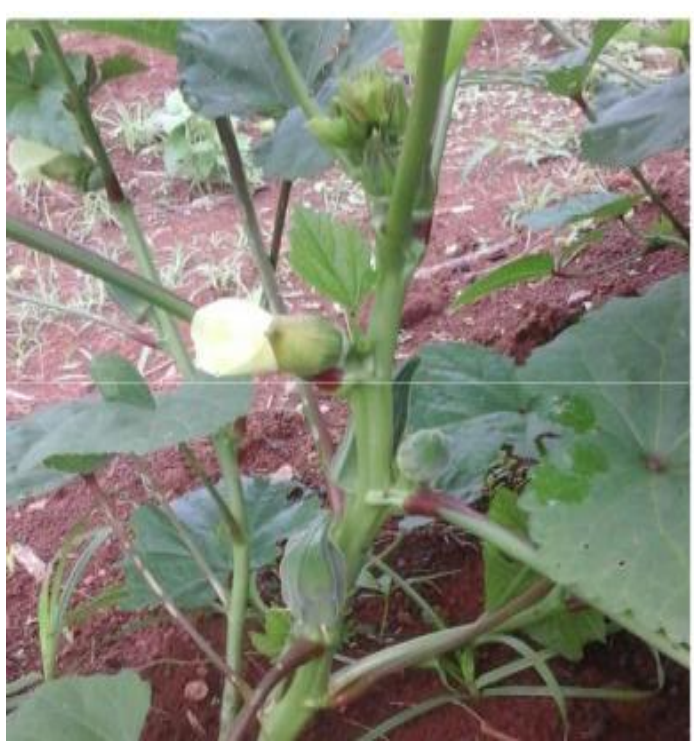

Figure3: Foot of Abelmoschus esculentus showing a flower in free pollination in Bilone in 2019

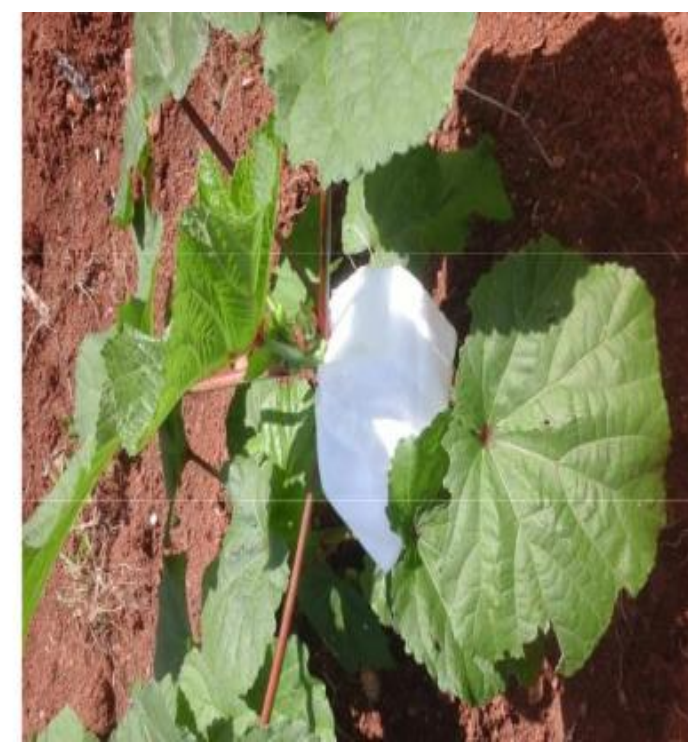

Figure 4: Foot of Abelmoschus esculentus showing a flower protected from insects with a cloth bag in Bilone in 2019

\subsection{Foraging Activity of Flowering Insects on Abelmoschus Esculentus Flowers}

Observations were conducted on 35 individually opened pollinated flowers of treatment 1 each day from May 14 to June 3 in 2019 and from May 19 to June 11 in 2020 at interval from 9am to 15pm (9$10 \mathrm{am}, 11-12,14-15 \mathrm{pm})$. In a slow walk along all labeled open flowers of treatment 1 , the identity of all insects that visited A. esculentus flowers was recorded. All insects encountered on flowers were recorded and the cumulated results expressed in number of visits to determine the relative frequency and the regularity index of flowering insects in the anthophilous entomofauna of A. esculentus.

Direct observations of the foraging activity of insects on flowers were made. The floral rewards (nectar and/or pollen) collected by the foragers during each floral visit were registered based on its foraging behavior for the same dates and time slots as that of the insect counts. Nectar foragers were expected to extend their proboscis to the base of the corolla and the stigma, while pollen gatherers were expected to scratch the anthers with their mandibles or legs [33].

In the morning of each observation day, the number of opened flowers was counted. The duration of visits (Jean-prost, 1987) and the foraging speed (number of flowers visited per minute) [8,34] were timed to the same dates and in three time slots from 8am - 14pm (8-9am, 10-11am and 13-14pm), using a stopwatch. Abundances (highest numbers of individuals simultaneously active) per flower and per 1000 flowers (A1000) were recorded on the same dates and time slots as that of the registration of the duration of visits. The first parameter was recorded as a result of direct counts. For the abundance per 1000 flowers, honey bees were counted on a known number of open flowers; A1000 $=\left[(A x / F x)^{*}\right.$ 1000], where $F x$ and $A x$ are respectively the number of flowers and the number of individual bees actually counted on $F x$ [8]. During the days of investigation, the temperature and humidity of the study site were recorded every $30 \mathrm{~min}$, from 9 am to $17 \mathrm{pm}$, using a thermo-hygrometer installed in the shade.

\subsection{Evaluation of the Impact of Pollinating Insects on Abelmoschus Esculentus Yields}

This evaluation was based on the impact of flowering insect on pollination, the impact of pollination on fruiting and the comparison of yields (fruiting rate, mean number of seeds per pod and percentage of normal or well developed seeds) of treatment 1 (unprotected flowers) and treatment 2 (bagged flowers). 
The fruiting rate due to the influence of foraging insects $(F r i)$ was calculated using the formula: $F r i=$ $\{[(F r 1-F r 2) / F r l] * 100\}$, where $F r 1$ and $F r 2$ are the fruiting rate in treatments 1 and 2 respectively. The fruiting rate of a treatment $(F r)$ was calculated as follows: $F r=\left[(F 2 / F 1)^{*} 100\right]$, where, $F 2$ is the number of pods formed and $F 1$ the number of viable flowers initially set [8]. At maturity, pods were harvested from all treatments. The mean number of seeds per pod and the percentage of normal seeds were then calculated for each treatment

\subsection{Data Analysis}

SPSS softs ware and Microsoft Excel were used for three tests: Student's $(t)$ for the comparison of means of two samples, correlation coefficient $(r)$ for the study of line relationship between two variables, Chi-square $\left(\chi^{2}\right)$ for the comparison of percentages.

\section{RESULTS AND DISCUSSION}

\subsection{Pod Production of Abelmoschus Esculentus}

In 2019, the podding index was $0.91(n=35)$ for treatment 1 and $0.71(n=35)$ for treatment 2 , while in 2020; it was $0.86(n=35)$ and $0.77(n=35)$ for the two treatments respectively. Consequently, in 2019 the allogamy rate was $21.98 \%$ and the autogamy rate was 78.02 . In 2020, the corresponding figures were $10.46 \%$ and $89.54 \%$. It appears that the A. esculentus used in our experiments has a mixed reproduction mode with the predominance of autogamy over allogamy, which produce fruit by both autogamy (auto and self-pollination) and crossbreeding (cross-pollination), like higher plants [32]. The significantly highest $\left(\chi^{2}=4.80 ; d d l=1 ; p<0.001\right)$ fruit yield as a function of the selfpollination in relation to cross -pollination agrees [35], who stated that sesame is a predominantly autogamous species. These results are in agreement with those of those of Free [1993], Angbanyéré \& Matthew [25], Njoya [21] and Amada [26], Azo'o [18] and Pando [27] respectively in UK, Burkina Fasso, Yaounde and Maroua who indicate the best performance of self-pollination than crosspollination. Although, these results contradict those of Andrade [36] who indicate the best performance of cross-pollination than self-pollination. This difference is due, may be to exchange of genetic material promoted by this type of pollination, increasing the heterozygosity of the embryon formed in the seeds [37].

\subsection{Activities of Insects}

\section{Diversity and Frequency of Floral Entomofauna of Abelmoschus esculentus}

Table 1 shows the diversity, frequency of visits, and floral products harvested by insects observed on the flowers of Abelmoschus esculentus in Bilone.

It appears from this table that six groups of pollinators visited the okro belonging to order Hymenoptera, Diptera, Lepidoptera, Coleoptera, Orthoptera and Nevroptera of class insecta during the flowering period. The number of Hymenoptera was higher $(84.76 \%)$, followed by Diptera (10.75 $\%)$, Lepidoptera $(03.56 \%)$, Nevroptera $(00.39 \%)$ and then both of Coleoptera $(00.31 \%)$ and Orthoptera $(00.23 \%)$. The results indicate that Hymenopterans are the major pollinators visiting Abelmoschus esculentus flowers in Bilone in 2019 and 2020. These findings are in close agreement with Azo'o [18], Pando [27] at Maroua, Amada [26] at Yaounde, in the flowers of Abelmoschus esculentus; Djonwangwé [38, 39] at Maroua, Pharaon [40] at Bilone on Vigna unguiculata and Allium cepa flowers; Pando [41, 42] in the flowers of Cajanus cajan and Zea mays at Maroua who studied the relative abundance of pollinator fauna of Abelmoschus esculentus during two successive seasons. Hymenopterans insects were higher. Also, Pharaon [14] at Obala reported nine species of Hymenopterans as predominant visitors of sesame flowers. Among the 1293 visits of 11 insect species recorded on Abelmoschus esculentus flower, Apis mellifera and Xylocopa olivacea were the most represented insects with 278 visits (44.27\%) and 342 visits (51.43\%), in 2019 and 2020, respectively. 
Table1. Diversity, frequency of visits, and floral products harvested by insects in the flowers of Abelmoschus esculentus in Bilone in 2019 and 2020.

\begin{tabular}{|c|c|c|c|c|c|c|c|c|}
\hline \multicolumn{3}{|l|}{ Insects } & \multicolumn{2}{|c|}{2019} & \multicolumn{2}{|c|}{2020} & \multicolumn{2}{|c|}{ Total } \\
\hline$\overline{\text { Order }}$ & Family & Genres and species & $n 1$ & $P 1(\%)$ & $n 2$ & $P 2(\%)$ & $n t$ & $P t(\%)$ \\
\hline \multirow[t]{11}{*}{ Hymenoptera } & Apidae & Apis mellifera $(\mathrm{Nt}, \mathrm{Po})$ & 169 & 26.91 & 203 & 30.53 & 372 & 28.77 \\
\hline & & Xylocopa olivacea (Nt, $\mathrm{Po})$ & 103 & 16.40 & 139 & 20.90 & 242 & 18.72 \\
\hline & & Amegilla sp. (Nt, Po) & 51 & 8.12 & 45 & 6.77 & 96 & 7.43 \\
\hline & Halictidae & Lipotriches collaris (Nt, Po) & 97 & 15.45 & 66 & 9.92 & 163 & 12.61 \\
\hline & & Lasioglossum sp. (Nt, Po) & 23 & 3.66 & 9 & 1.35 & 32 & 2.47 \\
\hline & & Lasioglossum albipes (Nt, Po) & 8 & 1.27 & - & - & 8 & 0.62 \\
\hline & & Seladonia sp. (Nt, Po) & 5 & 0.80 & 32 & 4.81 & 37 & 2.86 \\
\hline & Vespidae & Ammophila sabulosa $(\mathrm{Nt}, \mathrm{Po})$ & - & - & 6 & 0.90 & 6 & 0.46 \\
\hline & & (1 sp.) (Po) & 15 & 2.39 & 7 & 1.05 & 22 & 1.70 \\
\hline & & Synagris cornuta (Nt, Po) & 42 & 6.69 & 67 & 10.07 & 109 & 8.43 \\
\hline & Formicidae & $(1 \mathrm{sp}).(\mathrm{Po})$ & - & - & 9 & 1.35 & 9 & 0.70 \\
\hline Total & $\overline{04}$ & 11 & 513 & 81.69 & 583 & 87.67 & 1096 & $\overline{84.76}$ \\
\hline Coleoptera & Pyrochroidae & Hycleus affinis (Po) & 4 & 0.64 & - & - & 4 & $\overline{0.31}$ \\
\hline Total & $\overline{01}$ & 01 & 04 & 0.64 & 00 & - & 04 & 0.31 \\
\hline \multirow[t]{2}{*}{ Diptera } & Muscidae & Musca domestica $(\mathrm{Nt}, \mathrm{Po})$ & 65 & 10.35 & 54 & 8.12 & 119 & 9.20 \\
\hline & Syrphidae & Paragus barbonicus (Po) & 9 & 1.43 & 11 & 1.65 & 20 & 1.55 \\
\hline Total & $\overline{02}$ & 02 & 74 & 11.78 & 65 & 9.77 & 139 & 10.75 \\
\hline \multirow[t]{3}{*}{ Lepidoptera } & Acracidae & Acrea acerata $(\mathrm{Nt})$ & 23 & 3.66 & 9 & 1.35 & 32 & 2.48 \\
\hline & Nymphalidae & 1 sp. (Nt, Rt) & - & - & 3 & 0.45 & 3 & 0.23 \\
\hline & Pieridae & Eurema senegalensis (Nt) & 11 & 1.75 & - & - & 11 & 0.85 \\
\hline Total & $\overline{\mathbf{0 3}}$ & $\mathbf{0 3}$ & 34 & 5.41 & 12 & 1.81 & 46 & 3.56 \\
\hline Orthoptera & & 1 sp. (Df) & 3 & 0.48 & - & - & 3 & 0.23 \\
\hline Total & 01 & 01 & 03 & 0.48 & 00 & - & 03 & 0.23 \\
\hline \multirow[t]{2}{*}{ Nevroptera } & Libellulidae & Corcothemis erythraea $(\mathrm{Pr})$ & - & - & 3 & 0.45 & 3 & 0.23 \\
\hline & & 1 sp. (Pr) & - & - & 2 & 0.3 & 2 & 0.16 \\
\hline Total & 02 & 02 & 00 & - & 05 & 0.75 & 05 & 0.39 \\
\hline Total & 11 & 20 & 628 & 100 & 665 & 100 & 1293 & $\overline{100}$ \\
\hline
\end{tabular}

$n_{1:}$ number of visits on 35 flowers in 21 days. $n_{2}$ : number of visits on 35 flowers in 24 days. $p_{1}$ et $p_{2}$ : percentages of visits. $p_{1}=\left(n_{1} / 628\right) * 100 . p_{2}=\left(n_{2} / 665\right) * 100 . n_{1,2}=\left(n_{1}+n_{2}\right) \cdot p_{1,2}=\left[\left(n_{1}+\right.\right.$ $\left.\left.n_{2}\right) / 1293\right]^{*} 100$. Nt : visitor collected nectar. Po: visitor collected pollen. Df: defoliator. Rt: rest. Pr: predator. sp.: undetermined species.

The total species richness of Abelmoschus esculentu's flowering insects was 20 in Bilone. This specific richness is far inferior to that found by Pando et al. (2020) at Maroua, which was 32 species. The comparison between the two specific richness is highly significant $(t=723.81[d f=1089 ; P<$ 0.001]). This agrees the research of Roubik [29], which revealed that the diversity and specific richness of a plant's flowering entomofauna may vary in space and time.

It appears from table 1 against that there are three categories of insects: (a) species exclusively in search of nectar which was represented by Acrea acerata and Eurema senegalensis. Concerning Lepidoptera, Pando [27] reported in Maroua that these insects harvest only nectar on flowers. (b) species exclusively in search of pollen which was represented by Hycleus affinis, Paragus barbonicus and two undetermined species bilong to Vespidae and Formicidae Family. (c) Species in search of 
nectar and pollen were represented by: Apis mellifera adansonii, Xylocopa olivcea, Amegilla sp., Lipotriches collaris, Lasioglossum sp., Lasioglossum albipes, Seladonia sp. , Ammophila sabulosa, Synagris cornuta and Musca domestica, During this flowering period, these insects that collected pollen and nectar from visited the flowers of Abelmoschus esculentus, intensely collected nectar as pollen. These findings are in conformity with the observations made by Pando [27], who reported that the Hymenoptera harvested intensively the nectar than pollen. (d) One undetermined specie of Orthoptera Family consuming petals. It should be noted that some flies, butterflies, and lady beetles visit flowers for feeding on different parts of Abelmoschus esculentus and sometimes just for resting.

\section{Frequency of flowering insects of Abelmoschus esculentus}

Amongst the 628 and 665 visits of 15 and 16 insect species were recorded in two years (May 14 to June 03, 2019) and (May 19 to June 11, 2020) on A. esculentus, Apis mellifera, Xylocopa olivacea and Lipotrices collaris were the most frequently insect species observed, with 372 (28.77\%), 242 $(18.72 \%)$ and $163(12.61 \%)$ visits respectively (Table 1). The difference between these three percentages of visits is high significant $\left(\chi^{2}=12.43, d f=2, p<0.01\right)$.

The distribution of flower-visiting insect species according to their daily regularity is reported in table 2.

This table presents the number and percentage of days of visits of the different flowering insects from Abelmoschus esculentus. It appears from this table that the frequency of each insect species is varied. Three groups of anthophilous insects were found on A. esculentus flowers: (a) constant visitors $(f>$ 50): Apis mellifera adansonii, Xylocopa olivcea, Amegilla sp., Lipotriches collaris, and Musca domestica,; (b) accessory visitors with average frequencies (25<f $\leq 50 \%$ ): Lasioglossum sp., Synagris cornuta, Acraea serena and Paragus barbonicus; (c) Rare visitors $(f \leq 25 \%)$ represented by Lasioglossum albipes, Seladonia sp., Hycleus affinis, Corcothemis erythraea, Ammophila sabulosa and Eurema lactasana. The high frequency of some species is due to their attachment to the pollen and/or nectar of A. esculentus. For Apidae and Halictidae family's species, pollen is indispensable for their nutrition Roubik (2000). For Halictidae, this result agreed that Pando et al. (2019) were found on Glycine max flowers. In addition, the attractive nature of its flowers with insects is due to the color of the flowers, which is purple, the most attractive color, according to Faegri \& Piji [43].

Table2. Number and percentage of days of visits of the different flowering insects from Abelmoschus esculentus in Bilone in 2019 and 2020.

\begin{tabular}{|c|c|c|c|c|c|c|}
\hline \multirow[t]{2}{*}{ Insects } & \multicolumn{2}{|c|}{2019} & \multicolumn{2}{|c|}{2020} & \multicolumn{2}{|c|}{ Total } \\
\hline & $n 1$ & $f 1(\%)$ & $n 2$ & $f 2(\%)$ & $n t$ & $f t(\%)$ \\
\hline Apis mellifera $(\mathrm{Nt}, \mathrm{Po})$ & 21 & 100 & 24 & 100 & 45 & 100 \\
\hline Xylocopa olivacea $(\mathrm{Nt}, \mathrm{Po})$ & 21 & 100 & 24 & 100 & 45 & 100 \\
\hline Amegilla sp. (Nt, Po) & 10 & 46.62 & 13 & 54.17 & 23 & 51.11 \\
\hline Lipotriches collaris (Nt, Po) & 17 & 80.95 & 14 & 58.33 & 31 & 68.89 \\
\hline Lasioglossum sp. (Nt, Po) & 10 & 46.62 & 5 & 20.83 & 15 & 33.33 \\
\hline Lasioglossum albipes (Nt, Po) & 4 & 19.05 & - & - & 4 & 8.89 \\
\hline Seladonia sp. (Nt, Po) & 4 & 19.05 & 7 & 29.17 & 11 & 24.44 \\
\hline Ammophila sabulosa (Nt, $\mathrm{Po})$ & - & - & 3 & 12.50 & 3 & 6.67 \\
\hline Synagris cornuta (Nt, Po) & 9 & 42.86 & 12 & 50 & 21 & 46.67 \\
\hline Hycleus affinis (Po) & 2 & 9.52 & - & - & 2 & 4.44 \\
\hline Musca domestica (Nt, Po) & 21 & 100 & 24 & 100 & 45 & 100 \\
\hline Paragus barbonicus (Po) & 4 & 19.05 & 8 & 33.33 & 12 & 26.67 \\
\hline Acrea acerata $(\mathrm{Nt})$ & 17 & 80.95 & 5 & 20.83 & 22 & 48.89 \\
\hline Eurema senegalensis (Nt) & 6 & 28.57 & - & - & 6 & 13.33 \\
\hline Corcothemis erythraea (Pr) & - & - & 2 & 8.33 & 2 & 4.44 \\
\hline
\end{tabular}


$n 1$ : number of days of presence of insects during N1 observation days in 2019; $n 2$ : number of days of presence of insects during N2 observation days in 2020; nt: number of days of presence of insects during $\mathrm{N}$ t observation days in 2015 and 2018; $f 1$ (\%): Relative frequency of insect visits $(\mathrm{n} 1 / \mathrm{N} 1) * 100 ; f 2(\%)$ : Relative frequency of insect visits $(\mathrm{n} 2 / \mathrm{N} 2)^{*} 100 ; f t(\%)$ : Relative frequency of insect visits $(\mathrm{nt} / \mathrm{Nt}) * 100 ; \mathrm{N} 1=21, \mathrm{~N} 2=24, \mathrm{Nt}=45$

This table presents the number and percentage of days of visits of the different flowering insects from Abelmoschus esculentus. It appears from this table that the frequency of each insect species is varied. Three groups of anthophilous insects were found on A. esculentus flowers: (a) constant visitors $(f$ > 50): Apis mellifera adansonii, Xylocopa olivcea, Amegilla sp., Lipotriches collaris, and Musca domestica,; (b) accessory visitors with average frequencies $(25<f \leq 50 \%)$ : Lasioglossum sp., Synagris cornuta, Acraea serena and Paragus barbonicus; (c) Rare visitors $(f \leq 25 \%)$ represented by Lasioglossum albipes, Seladonia sp., Hycleus affinis, Corcothemis erythraea, Ammophila sabulosa and Eurema lactasana. The high frequency of some species is due to their attachment to the pollen and/or nectar of A. esculentus. For Apidae and Halictidae family's species, pollen is indispensable for their nutrition Roubik (2000). For Halictidae, this result agreed that Pando et al. (2019) were found on Glycine max flowers. In addition, the attractive nature of its flowers with insects is due to the color of the flowers, which is purple, the most attractive color, according to Faegri \& Piji [43].

\section{Relationship between visits and flowering stages}

We found a positive and significant correlation between the number of opened flowers and the number of insect visits (A mellifera) in $2019(r=0.56 ; d d l=9 ; P<0.05)$. Furthermore, a positive and highly significant correlation was found $(r=0.72, d d l=9, P<0.05)$ and a positive highly significant correlation $(r=0.80, d d l=9, P<0.05)$ between the number of opened flowers and the number of Hymenoptera insect visits in 2020.

\section{ImpaCt Of InSECTS on Abelmoschus esculentus Pollination}

When collecting pollen and/or nectar on flowers of A. esculentus insects were frequently in contact with the anthers and the stigma of visited flowers. They could therefore be directly involved in selfpollination, by putting pollen of one flower on to the stigma of the same flower. Table 3 presents the percentage of contacts between insect, anther, and stigma of A. esculentus.

It appears on that table that all the 15 insect species that visited the flowers had contact with the anthers and/or stigmas: (a) seven of these insect species have a frequency of contact with the anthers of $100 \%$, seven have an incidence of contact with the anthers of between $50 \% \leq \mathrm{f}<100 \%$ and one have a frequency of contact with the anthers of between $25 \% \leq f<50 \%$; (b) three of these insect species have a frequency of contact with the stigma of $100 \%$, eleven have an incidence of contact with the stigma of between $50 \% \leq f<100 \%$ and one have a frequency of contact with the stigma of between $25 \% \leq f<50 \%$. Individuals of each studied bee species were seen carrying pollen of $A$. esculentus from flower to flower, using the legs, mouthparts, thorax, and abdomen. Therefore, they were likely playing a positive role in geitogamy [32] by putting the pollen of one flower to the stigma of another flower of the same plant species. The foragers passing from flower to flower on different plants were seen carrying pollen from one plant to another. They could, therefore, allowed xenogamy [32], by putting the pollen of plant species to the stigma of another plant species. Several flowering insects in general and Apoidea family, in particular, were reported as being part of the pollinating entomofauna of A. esculentus in Cameroon by other authors such as Njoya [21], Amada [26] at Yaounde; Azoo'o [18] and Pando [27] at Maroua.

According to table 3, the different insect species found on A. esculentus flowers can be classified into three categories of pollinators: (a) major pollinators (Apis mellifera, Xylocopa olivcea, Lipotriches collaris, and Musca domestica) which are characterized by a high regulatory index ( $\mathrm{R}>0.05)$; (b) minor pollinators (Amegilla sp., Synagris cornuta and Acraea serena) which are characterized by a low regulatory index $(0.01<R<0.05)$. This could be explained by the low number of the species present in the experimental field, or the species were preferentially in search of nectar. (c) Occasional pollinators (Lasioglossum sp., Paragus barbonicus, Lasioglossum albipes, Seladonia sp., Hycleus affinis, Corcothemis erythraea, Ammophila sabulosa and Eurema lactasana) which are characterized with a very weak regulatory index $(R<0.01)$ and absence of behavior, link to the search of pollen and/or nectar but may have a destructive attitude. All these species of insects carry out foraging 
activities on the flowers of A. esculentus, thus contribute to auto pollination and/or cross-pollination. These, therefore, ensure the diversity of the species and increase the seeds yield and produce.

Table 3: Regularity index (R), numbers and percentage of insect visits in contact with the anthers and stigma of Abelmoschus esculentus flowers at Bilone.

\begin{tabular}{|c|c|c|c|c|c|c|c|c|}
\hline \multirow[t]{3}{*}{ Insects } & \multirow{3}{*}{$\begin{array}{r}2019 \\
R I\end{array}$} & \multirow{3}{*}{$\begin{array}{r}2020 \\
R 2\end{array}$} & \multirow{3}{*}{$\begin{array}{r}\text { Total } \\
R_{T}\end{array}$} & \multirow[t]{3}{*}{ Nt } & \multicolumn{4}{|c|}{ Number of contact visits of : } \\
\hline & & & & & \multicolumn{2}{|c|}{ Anthers } & \multicolumn{2}{|c|}{ Stigma } \\
\hline & & & & & $n_{a}$ & $p_{a}(\%)$ & $n_{s}$ & $p_{s}(\%)$ \\
\hline Apis mellifera & 0.2691 & 0.3053 & 0.2872 & 372 & 372 & 100 & 372 & 100 \\
\hline Xylocopa olivacea) & 0.1640 & 0.2090 & 0.1865 & 242 & 233 & 96.28 & 238 & 98.35 \\
\hline Amegilla sp. & 0.0379 & 0.0367 & 0.0373 & 96 & 96 & 100 & 96 & 100 \\
\hline Lipotriches collaris & 0.1251 & 0.0579 & 0.0915 & 163 & 163 & 100 & 148 & 90.80 \\
\hline Lasioglossum sp. & 0.0171 & 0.0028 & 0.0099 & 32 & 32 & 100 & 29 & 90.62 \\
\hline Lasioglossum albipes & 0.0024 & - & 0.0012 & 8 & 8 & 100 & 7 & 100 \\
\hline Seladonia sp. & 0.0015 & 0.0140 & 0.0077 & 37 & 37 & 100 & 31 & 83.78 \\
\hline Ammophila sabulosa & - & 0.0011 & 0.0006 & 6 & 6 & 100 & 4 & 66.67 \\
\hline Synagris cornuta & 0.0287 & 0.0503 & 0.0395 & 109 & 102 & 93.58 & 89 & 81.65 \\
\hline Hycleus affinis & 0.0006 & - & 0.0003 & 4 & 3 & 75 & 1 & 33.33 \\
\hline Musca domestica & 0.1035 & 0.0812 & 0.0924 & 119 & 116 & 97.48 & 118 & 99.16 \\
\hline Paragus barbonicus & 0.0027 & 0.0055 & 0.0041 & 20 & 14 & 70 & 17 & 85 \\
\hline Acrea acerata & 0.0296 & 0.0028 & 0.0162 & 32 & 22 & 68.75 & 25 & 78.12 \\
\hline Eurema senegalensis & 0.0050 & - & 0.0025 & 11 & 5 & 45.45 & 8 & 72.73 \\
\hline Corcothemis erythraea & - & 0.0004 & 0.0002 & 3 & 2 & 66.67 & 1 & 50 \\
\hline
\end{tabular}

$\mathrm{R}=(P n / 100)^{*}(f n / 100) ; P n$ : percentage of insect visits (Table 1$) ; f n$ : Relative frequency of insect visits (Table 2); $N \mathrm{t}^{\prime}$ : Number of total visits, $n_{\mathrm{a}}$ : number of contact anther visits; $P a$ : percentage of anther contact visits; $n_{\mathrm{s}}$ : number of contact stigma visits; Ps : percentage of stigma contact visits

The significant contribution of pollinating insects in pods and seed yield of A. esculentus was found in Cameroon [13] which showed that A. esculentus flowers produce fewer seeds per pod in the absence of pollinating insects. The weight of insect pollinators played a positive role during nectar or pollen collection, those insects shook flowers, facilitating the liberation of pollen by anthers for the optimal occupation of the stigma [17]. This Higher productivity of pods and seeds in unlimited visits when compared with bagged flowers showed that insect visits were effective in increasing cross-pollination.

\section{ImPaCt OF InSECt Pollinators on SEed YieldS of A belmoschus Esculentus}

During pollen and nectar harvest, flowering insects of A. esculentus were in regular contact with the anthers and stigma. Thus these insects increased the pollination possibilities of this plant species. Table 4 presents the results on the fruiting rate, the number of seeds per pod and the percentage of normal seeds in different treatments.

The number of fruit set, ten days after anthesis of flowers, and harvested showed significant differences $(p<0.05)$ between treatments of pollination in Bilone (Table 4$)$.

Table 4: Fruiting rate, number of seed per pod and percentage of normal seeds according to different treatments of Abelmoschus esculentus in 2019 and 2020 at Bilone

\begin{tabular}{|c|c|c|c|c|c|c|c|c|c|}
\hline \multirow{2}{*}{ Treatment } & \multirow{2}{*}{ Year } & \multirow{2}{*}{ Flowers } & \multirow{2}{*}{ Pods } & \multirow{2}{*}{ Fruiting rate (\%) } & \multicolumn{2}{|c|}{ Seed / Pods } & \multirow{2}{*}{$\begin{array}{l}\text { Total } \\
\text { Seeds }\end{array}$} & \multirow{2}{*}{$\begin{array}{c}\text { Normal } \\
\text { Seeds }\end{array}$} & \multirow{2}{*}{$\begin{array}{r}\% \text { normal } \\
\text { Seeds }\end{array}$} \\
\hline & & & & & $m$ & $s$ & & & \\
\hline Unlimited visits & \multirow{2}{*}{2019} & 34 & 34 & 100 & 81.60 & 19.06 & 2669 & 2474 & 92.69 \\
\hline Bagged flowers & & 30 & 28 & 93.33 & 61.90 & 14.96 & 2156 & 1845 & 85.57 \\
\hline Unlimited visits & \multirow{2}{*}{2020} & 34 & 32 & 94.12 & 84.02 & 3.26 & 2463 & 2374 & 96.39 \\
\hline Bagged flowers & & 30 & 27 & 90 & 71.48 & 9.67 & 1561 & 1423 & 91.16 \\
\hline
\end{tabular}

In Table 4, we documented: 
1. High fruiting rate of pod formation during unprotected visits compared with bagged flowers. The comparison of the fruiting rate showed that the differences observed were significant between treatments 1 and $2\left(\chi_{2019}^{2}=2.34[d f=1 ; P<0.05]\right)$ and non significant between treatments 3 and 4 $\left(\chi^{2}{ }_{2020}=0.38[d f=1 ; P>0.05]\right)$. The results suggest that the type of pollination effect of the fruiting rate. So, the visit by biotic pollinators is important for Abelmoschus esculentus pollination, whether increasing the efficiency of pollen transfer within the same flower or even bringing pollen from other flowers, providing cross - pollination. Similar results were obtained in Maroua by Pando [27] was $9.57 \%$. This could be due to absence or its lower abundance of the same major pollinators.

2. High mean number of seeds per pod in unlimited visits compared with bagged flowers. The comparison of the mean number of seeds per pod has shown that the difference observed was highly significant between treatments 1 and $2\left(\mathrm{t}_{2019}=17.17[d f=60 ; P<0,001]\right)$ and treatments 3 and $4\left(t_{2020}=\right.$ $25.90[d f=57 ; P<0.001])$. The percentage of the number seeds per pod due to the action of insects was $16.12 \%$ for the both years. In the same idea, Azo'o [18] found the corresponding result at Maroua of $9.50 \%$.

3. Higher normal seed yield for unlimited visits treatment compared with bagged flowers. The comparison of the percentage of normal seeds showed that the observed differences were very highly significant between treatments 1 and $2\left(\chi_{2019}^{2}=64.38[d f=1 ; P<0.001]\right)$ and treatments 3 and 4 $\left(\chi^{2}{ }_{2020}=49.04[d f=1 ; P<0.001]\right)$. The Normal seed yield in unprotected flowers for unlimited visits (1 and 3) was higher than that in the bagged flowers (2 and 4). The percentage of normal seeds attributed to the influence of insects was $2.61 \%$ for the both years. This result is inferior to what was obtained by Pando [27] at Maroua, which was $04.34 \%$. The difference in this value could be explained by the presence of more pollinating species at Maroua.

The numeric contribution of Hymenoptera to the mean number of seeds per pod and the percentage of normal seeds were respectively $20.59 \%$ and $2.38 \%$ in 2019 . The corresponding figures were $20.87 \%$ and $5.28 \%$ in 2020 . For the two cumulate years, the numeric contributions were $20.73 \%$ and $3.83 \%$ for the mean number of seeds per pods and the percentage of normal seeds respectively. The impact of Hymenoptera on pod and seed yields was positive and significant.

\section{CONCLUSiON}

The floral products of A. esculentus attract pollinator insects. This attractiveness is of benefit for the pollination process. The comparison of pods and seeds set of unprotected flowers with that of protected flowers indicated the value of these insect pollinators in increasing pods and seed yields. In Bilone, A. esculentus is a mixed pollination plant, able to self-pollinate and reach levels above $93 \%$ fruit set, but with potential for a significant increase in fruit production in the presence of biotic pollinators that promote cross-pollination as Hymenoptera (20.73\%). Twenty species of insects distributed in eleven families and five orders visited the flowers of A. esculentus to harvest nectar and/or pollen. Hymenoptera were the most frequent order with $84.76 \%$, followed by Diptera (10.75 $\%$ ) and others (Coleoptera, Lepidoptera, Orthoptera and Nevroptera: $04.49 \%$ ). Comparing the yield of unlimited flowers with insect-bagged flowers, it is observed that Hymenoptera increase the number of seeds/fruit and the normal seeds to $20.73 \%$ and $03.83 \%$ respectively. The treatment of okro plants with chemical pesticides should be avoided during the flowering period in order to benefit from the ecosystem service of pollinating insects. Pollinators could be protected by rational pest management tactics, i.e., pesticide application, if needed, should be done in the late afternoon to protect the pollinators for high seed yield or spray at a time of day when crop flowers are closed. More, the installation of nests or hives of insect pollinators in general, and Hymenoptera in particular, at the proximity of A. esculentus fields should be recommended for the increase of pods and seed yields of this valuable crop.

\section{REFERENCES}

[1] McGregor S. E., Insect pollination of cultivated crop plants. Agricultural Research Service. United States Department of Agriculture, Agriculture Handbook, Washington, no. 496, pp. 411 (1976).

[2] Louveaux J., Domestic bee and their relation with grown plants. «Pollination and plant production». Pesson P, Louveaux J, INRA, Paris, France, pp. 527 - 555 (1984).

[3] Guerriat H., Etre performant en apiculture. Guerriat (ed.), Daussois, 416 p (1996). 


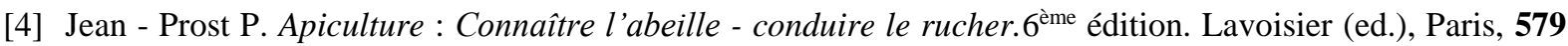
$\mathrm{p}(1987)$.

[5] DSCE., Document de Stratégie pour la Croissance et l'Emploi. MINEPAT. Yaoundé, Cameroun, 1-112 (2009).

[6] chuenguem F. F. - N. and Dounia, Foraging and pollination behavior of Apis mellifera adansonii Latreille (Hymenoptera: Apidae) on Glycine max L. (Fabaceae) flowers at Maroua. Journal of Research in Biology, 4 (1): 1209-1219 (2014).

[7] Delbrassine \& Rasmont P., Contribution à l'étude de la pollinisation du colza, Brassica napus L. var oleifera (Moench) Delile, en Belgique. Bulletin de la Recherche Agronomique, 23 (2), 123-152 p (1988).

[8] Tchuenguem F. F.-N., Foraging and pollination activity of Apis mellifera adansonii Latreille (Hymenoptera: Apidae, Apinae) on flowers of three plants at Ngaoundéré (Cameroon): Callistemon rigidus (Myrtaceae), Sygygium guineense var. macrocarpum (Myrtaceae) and Voacanga Africana (Apocynaceae). State doctorate, University of Yaounde I. Pp. 103 (2005).

[9] Djonwangwé D., Activités de butinage et de pollinisation de Apis mellifera adansonii Latreille (Apidae, Apinae) sur les fleurs de trois plantes à Ngaoundéré (Cameroun). Thèse de Doctorat/Ph.D., Université de Yaoundé I, 207 p (2013).

[10] Kingha T. M. B., Entomofaune floricole et son impact sur les rendements fruitiers et grainiers de Arachis hypogaea L. et Phaseolus vulgaris L. (Fabaceae) à Dang (Ngaoundéré-Cameroun). Thèse de Doctorat/Ph.D., Université de Ngaoundéré; 139 p (2014).

[11] Kumar R., La lutte contre les insectes ravageurs. KARTHALA et CTA (eds), Wageningen, Paris, 309 p (1991).

[12] Philippe J. M., La pollinisation par les abeilles: pose des colonies dans la culture en floraison en vue d'accroître les rendements des productions végétales. EDISUD la calade Aix-en-Provence. Pp. 179 (1991). $*$

[13] Klein, A.M.; Vaissière, B.E., Cane, J.H.; Steffan-Dewenter, I.; Cunnigham, S.A.; Kremen, C., Tscharntke, T., Importance of pollinators in changing landscapes for world crops. Proceedings of the Royal Society, 274, 303 - 313 (2007).

[14] Pharaon, M.A.; Dounia, Douka, C.; Otiobo, A.E.N.; Tchuenguem, F.F-N., Pollination Efficiency of Apis mellifera L. (Hymenoptera: Apidae) on Flowers of Sesamum indicum L. (Pedaliaceae) at Bilone (Obala, Cameroon). International Journal of Research Studies in Agricultural Sciences, 4, 12-20 (2018).

[15] Georges, R.A.T., Vegetable seed production. Longmon Scientic and Technical, London and New-York, 1318 (1989).

[16] Sawadogo M, Zombre G, Balma D., Expression de différents écotypes de gombo (Abelmoschus esculentus L.) au déficit hydrique intervenant pendant la boutonnaison et la floraison. Biotechnology, Agronomy, Society, Environment. 10:43-54 (2006).

[17] Al-Ghzawi AM, Zaittoun ST, Makadmeh I, Al Tawaha ARM. The impact of wild bee on the pollination of eight okra genotypes under semi-arid Mediterranean conditions. International Journal of Agriculture and Biology. 5:409-411 (2003).

[18] Azo'o EM, Tchuenguem FF-N. and Messi J., Influence of foraging entomofauna on Okra (Abelmoschus esculentus) seed yields. International Journal of Agriculture \& Biology, 13: 761-765 (2011).

[19] Azo'o EM, Madi A, Tchuenguem FF-N, Messi J., The importance of a single floral visit of Eucara macrognatha and Tetralonia fraterna (Hymenoptera: Apidae) in the pollination and the yields of Abelmoschus esculentus in Maroua, Cameroon. African Journal of Agricultural Research. 7(18):2853-2857 (2012).

[20] Hamon S. Organisation évolutive du genre Abelmoschus (Gombo) : coadaptation et évolution de deux espèces de Gombo cultivées en Afrique de l'Ouest (A. esculentus et A. caillei). Ed. ORSTOM. Paris, France. 26 p (1987).

[21]Njoya MT, Wittmann D., and Schindler M. Effect of Bee Pollination on Seed Set and Nutrition on Okra (Abelmoschus esculentus) in Cameroon. The Global Food \& Product Chain-Dynamics, Innovations, Conflicts, Strategies. Deutscher Tropentag, Hohenheim. 11-13 pp (2005).

[22] Olugbenga EI. and Eludire MO., Floral Biology and Pollination Ecology of Okra (Abelmoschus Esculentus L. Moench), American International Journal of Biology, 2.; (2) : 1-9 (2014).

[23] Crane E., Apis species of tropical Asia as pollinators and some rearing methods for them. Acta Horticultural. 288: $29-48$ (1991).

[24] Free, J.B. Leguminosae: Phaseolus. In: “Insect Pollination of Crops, ” Academic Press (ed.), London, pp., 264-270 (1993). 
[25] Angbanyere \& Matthew A-IRE. The effect of pollinators and pollination on fruit set and fruit yields of okra (Abelmoschus esculentus (L) Moench) in the forest region of Ghana. Thèse de doctorat, Kwame Nkrumah University of Science and Technology College of Science. 103 p (2012).

[26] Amada B., Dounia, Douka, Ningatoloum C., Gateuh Guiffo AA., Angoula BS., Ngonaïna JP., Tamesse JL., and Tchuenguem F F-N., Diversity of flowering insects and their impact on yields of Abelmoschus esculentus (L.) Moench, 1794 (Malvaceae) in Yaoundé (Cameroon), Journal of Entomology and Zoology Studies, 6 (6) : 945 - 949 (2018)

[27] Pando JB., Djonwangwé D., Moudelsia OB., Tchuenguem F F-N., Tamesse JL., Effect of Insect Pollination on The Yield of Sesamum indicum (Pedaliaceae) In Maroua-Cameroon, Journal of Advances in Ariculture, 11 (2020). DOI : https://doi.org/10.24297/jaa.v11i.8633

[28] MINADER, Annuaire des Statistiques du Secteur Agricole, Campagnes 2009 \& 2010. Direction des Enquêtes et Statistiques AGRI - STAT CAMEROUN n 17, Pp. 123 (2012).

[29] Roubik D. W., Pollination system stability in Tropical America. Conserv. Biol., 14 (5): 1235-1236 (2000).

[30] Letouzey R., Notice de la carte phytogéographique du Cameroun au 1/500000. Inst. Carte Intern. Végétation, Toulouse et Inst. Rech. Agron., Yaoundé (1985).

[31] Suchet J. P., Les climats du Cameroun. Thèse de Doctorat d'Etat, Université de Bordeaux-France, Pp.7971097 (1988).

[32] Delaplane KS, Dag A, Danka GR, Breno M, Freitas MB, Garibaldi L et al., Standard methods for pollination research with Apis mellifera. Journal of Apicultural Research. 52(4):1-18 (2013).

[33] Kasper, M.L., Reeson, A.F., Mackay, D.A., Austin, A.D., Environnemental factors influencing daily foraging activity of Vespula germanica (Hymenoptera, Vespidae) in Mediterranean Autralia. Insect Sociaux, 55, 288-296 (2008).

[34] Jacob - Remacle A., Comportement de butinage de l'abeille domestique et des Abeilles, 1989

[35] WEISS, E.A. Sesame. In: WEISS, E.A. (Ed.)., Oilseed crops. London: Longman, 282-340 (1983).

[36] Andrade, P.B.D.; Freitas, B.M.; Rocha E.E.D.M.; Lima, J.A.; Rufino, L.L. Floral Biology and pollination requirements of sesame (Sesamum indicum L.). Maringá, 36, 93-99 (2014).

[37] Mahfouz H.M., Kamel S.M., Belal A.H. and Said M., Pollinators visiting sesame (Sesamum indicum L.) seed crop with reference to foraging activity of some bee species. Cercetâri Agronomice în Moldova, XLV (2): 150-161 (2012).

[38] Djonwangwé D, Pando JB, Tchuenguem FF-N. and Messi J., Impact de l'activité de butinage de Xylocopa inconstans (Hymenoptera : Apidae) et de Megachile eurymera (Hymenoptera : Megachilidae) sur la pollinisation de Vigna unguiculata (Fabaceae) à Maroua (Extrême - Nord, Cameroun). Afrique Science, 13(5) (2017) 1 - 17 (2017).

[39] Djonwangwé D, Pando JB. and Tchuenguem FF-N:. Diversity of flowering insects of Allium cepa L. 1753 (Liliaceae) at Dogba and Gazawa (Diamaré, Far North Region, Cameroon). Journal of Chemical, Biological and Physical Sciences, 9(2): 281-296 (2019).

[40] Pharaon M.A., Douka C., Dounia, Eloundou CE., Tchuenguem, F.F-N., Pollination efficiency of Apis mellifera L. (Hymenoptera: Apidae) on flowers of Vigna unguiculata (L.) Walp. (Fabaceae) at Bilone (Obala, Cameroon), International Journal of Biosciences, 4, 12-20 (2020).

[41] Pando JB, Djonwangwe D, Balti MO, Tchuenguem FF-N. and Tamesse JL., Insect floral visitors of pigeon pea (Cajanus cajan L. Millsp.) and impact of the foraging activities on the pollination, pod and seed yields at Maroua - Cameroon. Journal of Biodiversity and Environmental Sciences, 12(4):48-58 (2018).

[42] Pando, J.B., Djongwangwé, D., Balti, M.O., Tchuenguem, F.F-N., Tamesse, J.L., Insect pollinators and productivity of soybean [Glycine max (L.) Merr.1917] at Maroua, Far North, Cameroon. World Journal of Advanced Research and Reviews, 4, 117 - 129 (2019).

[43] Faegri, K., Pijl, L.V.D., The principles of pollination ecology. Ed., Pergamon Press, New-York, $2^{\text {nd }}$ revised, NY. 1 - 291 (1971)

Citation: Pharaon Mbianda Auguste, et.al., (2021). “Impact of Hymenoptera on Abelmoschus Esculentus (L.) Moench, 1794 (Malvaceae) Seed Yields at Bilone (Obala, Cameroon)”, International Journal of Research Studies in Agricultural Sciences (IJRSAS), 7(8), pp. 1-12 DOI: http://dx.doi.org/10.20431/24546224.0708001

Copyright: (c) 2021 Authors. This is an open-access article distributed under the terms of the Creative Commons Attribution License, which permits unrestricted use, distribution, and reproduction in any medium, provided the original author and source are credited. 